\title{
Capital gains and wealth distribution in Italy
}

\author{
Luigi Cannari, Giovanni D'Alessio and Romina Gambacorta ${ }^{1}$
}

\section{Introduction ${ }^{2}$}

In the last fifteen years, asset prices have undergone sizeable changes. Between 1987 and 1992 , the prices of houses rose by about 80 per cent in real terms, decreasing by more than 20 per cent in the following five years, and quickly increasing again thereafter. Stock prices rose until 2000 , only to fall by more than 40 per cent in the following two years and then increase yearly by about 15 per cent between 2003 and 2005 .

This paper tries to assess the impact of these price variations on the amount of wealth held by Italian households. We focus on the specific role played by capital gains, i.e. wealth variations solely determined by changes in asset prices. Examining capital gains is important in many respects: they directly affect wealth distribution based on their size and dispersion, and they also have an impact on household consumption and labour supply. ${ }^{3}$

In order to explain how capital gains may affect wealth distribution let us consider three families, endowed at the end of the 1980s with the same amount of wealth in cash and the same conditions of access to financial markets. The first family buys the most profitable asset at the beginning of the year, the second one buys the less profitable one, and the third buys a fifty-fifty combination of the two. After two years, the financial wealth held by the first family surpasses by 65 per cent that of the second family, and by 26 per cent that of the third. In 2004, the first family's wealth amounts to 30 times that of the second and 5 times that of the third. Even if we take into account high transaction costs, wealth inequality between these households grows substantially over time. The example is based on very simple hypotheses, ${ }^{4}$ but it already tells part of the story: capital gains may have a substantial impact on the wealth of individual households as well as on the shape and concentration of wealth distribution.

The paper is organized as follows. In the next section we discuss the various definitions of capital gains and the main results obtained in the literature. Section 3 reports the macroeconomic estimates, while Section 4 shows the microeconomic analysis, describing the data and the methodology used. The effects of capital gains on the level and the distribution of household wealth in Italy are illustrated in Section 5. Finally, Section 6 reports the main conclusions.

1 Bank of Italy, Economic Research Department.

2 The authors wish to thank Claudia Biancotti, Ivan Faiella, Massimo Omiccioli, Luigi Federico Signorini and Francesco Zollino for their helpful comments and Giovanni Guazzarotti and Salvatore Muzzicato for their assistance in data collection. The views expressed herein are those of the authors and do not necessarily reflect those of the Bank of Italy.

3 See, among the others, Henley (2001), Mankiw and Zeldes (1991), Attanasio, Banks and Tanner (1998), Paiella (1999). For Italy, Zollino (2001) does not find relevant effects of capital gains on consumption expenditure, while Paiella (2004) shows that the effect of wealth on consumption, although slight, is statistically significant. Wealth variations accruing to real estate appear to influence consumption more than variations in financial wealth.

4 We referred to average returns for each class of assets. This set-up excludes within-class variability in asset prices. For example, between 1987 and 1992, the prices of houses in real terms more than doubled in Milan and Rome while, in the same period, they rose by a mere 10 per cent in smaller cities such as Ancona and Potenza (Bank of Italy, 2002). Price volatility in the stock market is even more evident. Finally, the example excludes intra-annual price variations. 


\section{Capital gains: definitions and theoretical framework}

\section{Definitions}

Following the national accounts (NA) definition, capital gains ${ }^{5}$ represent the changes in wealth due to the variation in the prices of its components. ${ }^{6}$ The overall variation in wealth $W_{t}$ can be decomposed in capital gains $C G_{t}$, net savings $S_{t}$ and net transfers $T_{t}$ (transfers received net of transfers paid): ${ }^{7}$

$\Delta W_{t}=S_{t}+T_{t}+C G_{t}$

Capital gains can be classified into neutral $C G_{t}^{N}$, which are related to variations in prices due to the inflation rate, and real $C G_{t}^{R}$ for the remaining part:

$$
C G_{t}=W_{t} \pi_{t}+\sum_{a} p_{a t} W_{a t}=G C_{t}^{N}+C G_{t}^{R}
$$

where $W_{a t}$ is wealth at time $t$ invested in asset $a, \pi_{t}$ is the average inflation rate, while $p_{a t}$ represents the variation in the price of asset $a$ that exceeds the yearly inflation rate. ${ }^{8}$

In what follows we will concentrate on real capital gains, which have effects on the distribution of purchasing power between households. Following the NA approach, we do not distinguish between either cashed and not-cashed capital gains or between expected and unexpected capital gains. ${ }^{9}$

Capital gains are not the only source of capital returns, as the latter may sometimes take the form of income (interest and dividends). Different assets show a different composition of these return components. For example, current accounts generate a capital income (interest) and no capital gains, while some investment funds generate only capital gains. Stocks lie somewhere in between as they yield both income (dividends) and capital gains.

From a conceptual point of view, capital gains differ from capital income in that they are not distributed to the owner, but remain included into the asset value: in order to cash them the owner needs to sell the asset. If the owner does not take any action, capital gains are reinvested in the asset that generated them. In addition, capital gains are much more volatile than capital income. For this reason they can have a different impact on consumption behaviour, especially when high transaction costs discourage the owner from cashing them.

Keeping in mind the different nature of these sources of capital revenue, the NA income definition adopted in this paper includes capital income and not capital gains. Savings are

5 We use the catch-all "capital gains" label for both positive and negative changes.

6 In a theoretical framework, only price changes unrelated to quality or quantity changes should be employed to calculate capital gains. In practice, the available price indexes do not always account for this. For example, when considering dwellings, the market price index is standardized with respect to the size, location and condition of the house, but not with respect to other possible sources of heterogeneity. Similarly, for stock prices, the MIB index does not disentangle profits that have not been distributed. Nevertheless, these assumptions do not appear to have a large impact on the results, as confirmed by some empirical experiments (for example, we measured the ratio between reserve budget and net capital for industrial firms).

7 This scheme basically follows the definitions of the European System of Accounts (ESA95).

8 The choice of the inflation rate as wealth deflator is not straightforward. Wealth is a reserve of valuables that is normally accumulated for future consumption. In order to deflate wealth properly, it would be necessary to know future prices, interest rates etc. On this topic see Reiter (1999).

9 In the literature the first distinction is mainly related to taxation issues (Haig, 1921; Simons, 1938; Hicks, 1939); for a recent review, see Harris (2001). See also Edrey (2004). 
computed as the difference between income and consumption, and therefore do not include wealth variations generated by changes in asset prices.

Where the distinction between expected and unexpected capital gains is concerned, it is worth pointing out that capital gains, despite their high volatility, cannot be considered completely random. When deciding portfolio allocation, investors will take into account the opportunities for both income revenues and capital gains. Following this view, the expected component of capital gains should be added to capital incomes; in this case, the definition of capital gains proper would refer only to the deviation from the average value due to the random component. However, we will not adopt this distinction for two reasons. First of all, it is difficult to select asset price models that account for the time horizon of investors and for their heterogeneity. The estimation of expected capital gains is therefore dependent on subjective assumptions. Secondly, the long-run average of capital gains is normally much smaller than their variability, so that the correction has only slight effects on short- to medium-run estimates.

\section{Capital gains and wealth}

The literature dealing with the effects of capital gains on wealth mainly refers to the British and American markets, where share ownership is more common than in Italy and wealth is therefore more dependent on the variability of stock prices. Research has focused mainly on the impact of asset price variations on the economic behaviour of households ${ }^{10}$ and less attention has been devoted to the role of capital gains on wealth accumulation and inequality, even if there is a body of evidence showing that this aspect is important. For example, Greenwood and Wolff (1992) find out by way of a simulation model that capital gains are responsible for about one-third of the average growth in household wealth observed between 1962 and 1983 in the United States. Using the same methodology, Wolff (1999) confirms that this result also holds for the following ten years; cohort analysis shows that the contribution is larger for the oldest groups. When considering the effects of capital gains on inequality, Henley (1998) shows that in the United Kingdom between 1985 and 1991 concentration in household wealth grew as a consequence of the variations in house prices; this effect was partially curbed by the rise in the number of house owners.

In Italy, variations in house prices can have a large effect on household net wealth, because real assets account for the lion's share of households' portfolios. On the other hand, the impact on inequality is presumably lower as most families own the house they live in.

In the last few years, Italian households have progressively participated more in the stock market, ${ }^{11}$ and the high variability of stock prices has increased the importance of capital gains for both the variance and the distribution of household net wealth. Cannari et al. (2003) show that, during the second part of the 1990s, cross-regional differences in per capita wealth grew as a consequence of variations in the prices of financial assets.

Summing up, the literature on the effects of capital gains on wealth, although mainly related to the British and American economies and adopting a different approach to the one we favour, shows that the contribution of capital gains to wealth is substantial. Thus, given the variation in the composition of portfolios held by Italian households and the recent variability of asset prices, capital gains could have played a significant role in the accumulation of wealth and in the evolution of inequality in Italy. In the rest of the paper we analyse these aspects using NA figures and data from the Bank of Italy's Survey of Household Income and Wealth (SHIW).

10 See, for example, Hendershott and Peek (1985), Peek (1986) and ECB (2003).

11 In Italy, during the 1990s, the share of household wealth invested in the riskiest assets (shares, investment funds and bonds) grew considerably. On these aspects see Cannari, D'Alessio and Paiella (2006). 


\section{Macroeconomic estimates}

On a macroeconomic level, we can obtain an estimate of the relative importance of savings and capital gains for household wealth using two sources. Savings are derived from NA estimates for households and non-profit institutions. Levels of household wealth are derived, up to 2002, from Brandolini et al. (2004) and updated using the same methodology. Finally, capital gains are obtained as the difference between the variations in wealth and savings.

Figure 1 shows the estimates of household savings, capital gains and wealth variations in the period 1990-2004. Savings, expressed at 2004 prices (using the consumer price index for the whole nation), gradually decreased from $€ 192$ billion to $€ 75$ billion between 1990 and 2000 , rising slightly in the following years.

Figure 1

\section{Household savings, capital gains and wealth variations}

Billion euros; 2004 prices

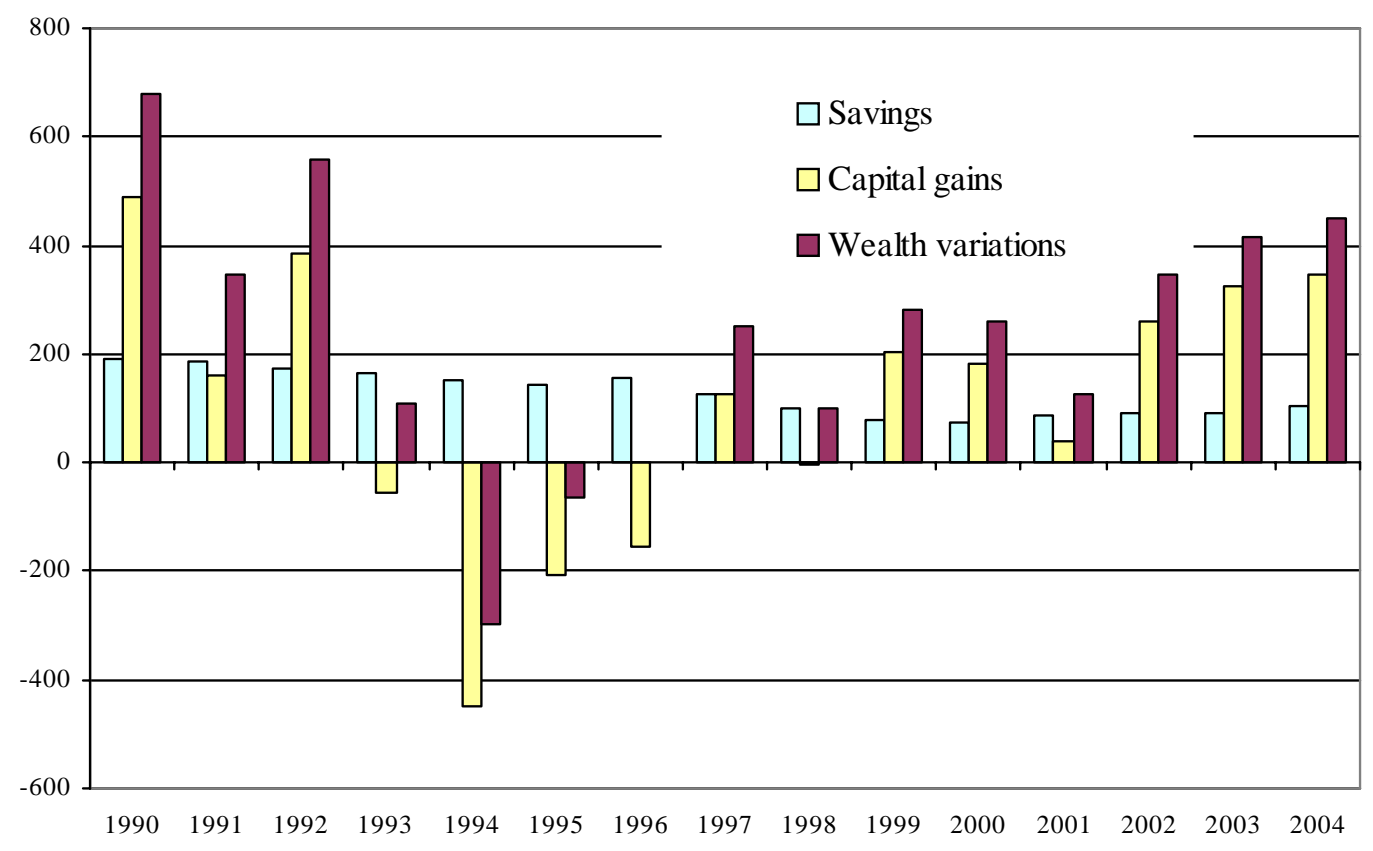

Source: Authors' calculations on data from Istat and Bank of Italy. Savings exclude depreciation. Wealth and savings are deflated using the consumer price index for the whole nation.

On the other hand, wealth variations exhibit a more volatile profile than savings owing to changes in asset prices. In particular, at the beginning of the period wealth changes were mainly driven by house prices, which rose until 1992 and fell by more than 20 per cent between 1993 and 1999, rising again in the following years. In the second half of the period, stock prices greatly influenced wealth variation as they rose until 2000 , decreased sharply in the following two years and recovered thereafter.

Overall, between the end of 1989 and 2004, household net wealth at 2004 prices grew by $€ 3,573$ billion, from $€ 4,712$ billion to $€ 8,285$ billion. In the period $1990-2004$, household net 
saving amounted to $€ 1,920$ billion, equal to 53.7 per cent of the increase in net wealth. In the same period, capital gains accounted for almost half of the variations in household wealth. ${ }^{12}$

Between 1990 and 2004 capital gains equalled, on average, 12.6 per cent of households' disposable income, while capital income was equal to 32.1 per cent. ${ }^{13}$ It should be noted that capital gains showed high variability during the observed period. During half of the period they exceeded (in absolute terms) one-fifth of disposable income. The sum of capital gains between 2002 and 2004 was equal to disposable income in 2004.

While these results show the importance of capital gains in the process of wealth accumulation, they still do not give any information about the impact on different categories of households and on inequality. These aspects are analysed in the following paragraphs.

\section{Microeconomic data}

Since 1962 the Bank of Italy has conducted its Survey of Household Income and Wealth (SHIW) with the aim of gaining deeper insight into the economic behaviour of households. The sample includes approximately 8,000 households and is drawn using a two-stage sample design. ${ }^{14}$ The questionnaire collects information on demographics, income, consumption, savings, wealth and several other topics. Further details of the survey can be found in Bank of Italy (2006); in the rest of this paragraph, the emphasis will be on the aspects related to wealth evaluation. ${ }^{15}$

\section{Household wealth in the SHIW}

Net household wealth is defined as the sum of real assets (dwellings, firms, valuables and durable goods) plus financial assets (deposits, government securities, bonds, shares, etc.) minus financial debts (mortgage and other debts). ${ }^{16}$ On the other hand, we do not include in this definition cash, the part of the TFR retirement fund ${ }^{17}$ already accumulated, and the actual value of the amount accumulated in private or public retirement funds because these items are not available in the survey. Interviewees were also asked to price each wealth component according to their beliefs. ${ }^{18}$ Comparing SHIW data on wealth with those from

12 During the 1980s, capital gains were mainly negative and sometimes larger (in absolute value) than savings. Between 1981 and 2004, capital gains represented about 29.6 per cent of real net wealth variation.

13 Capital incomes include: rents for dwellings and land, distributed profits from corporations and quasicorporations to households, profits invested abroad, interests, insurance profits and insurance incomes. They do not include mixed incomes.

14 Since 1989 a part of the sample (about 50 per cent in the last surveys) is composed of households already interviewed in previous surveys (panel households). It is therefore possible to focus accurately on themes such as income, wealth and changes in job status.

15 In this paper our calculations are based on data from the SHIW historical database, which contains information collected from 1977 to 2004.

16 Where the distinction between direct and portfolio investments is concerned, firms are regarded as real assets when they are run (completely or partially) by the owner, while they are considered to be financial assets if shares are held only as a form of investment of savings. Consistently with the definition usually adopted in official Bank of Italy publications, durable goods are treated as a component of wealth.

17 When leaving a job, workers in Italy are entitled to a lump-sum payment, called Trattamento di Fine Rapporto (TFR); it represents a form of compensation due on departure, irrespective of the reason. For further details see Schivardi and Torrini (2004).

18 The questionnaire does not specify any evaluation criterion for financial assets. We therefore presume that the subjective value provided by the interviewees is equal to the market price at the end of the year for shares, 
other sources such as NA, it is possible to notice some differences due to problems with the quality of the data collected in the survey, probably due to non-response of the richest households and to widespread non-reporting and under-reporting where asset ownership is concerned. ${ }^{19}$

It is necessary to account for the fact that response and reporting problems are dependent on the level of household wealth. For this reason we refer to the net wealth reconstruction method proposed by Brandolini et al. (2004). ${ }^{20}$ This correction procedure yields a level of net wealth that exceeds the baseline survey estimates by an average of 40 per cent. Furthermore, it modifies the relative shares of wealth components; in particular, it increases the share of financial assets relative to real assets. For example, in 2004, after the correction, financial assets rise from 9 to 15 per cent of net wealth, while real assets decrease from 94 to 87 per cent (Figure 2). ${ }^{21}$

\section{The estimation of capital gains}

The estimation of capital gains is based on equation (2) and uses a separate price index for each wealth component. For dwellings (primary residence and other dwellings) we use the average provincial indexes calculated by Muzzicato et al. (2002). These are based on data gathered by the magazine "Il Consulente immobiliare" and modified to account for national price variations observed in the survey, distinguishing between main municipalities and other towns. $^{22}$ Land has been priced following Povellato (1997). We assume that durable goods and other valuables do not generate any capital gains; apart from a few exceptions (such as cars and other means of transport), the former do not have a secondary market, ${ }^{23}$ and there is no available price index for the latter, which anyway only constitute a small part of wealth. As to the value of firms, ${ }^{24}$ we use the deflator of fixed capital stock (not including construction).

investment funds and other listed assets, and to their nominal value for the rest, such as government securities. On the other hand, when referring to debts, the questionnaire specifically requires the nominal value of the residual capital.

19 These subjects have been widely studied in the recent past. See D'Alessio and Faiella (2002), Cannari et al. (1990), Cannari and D'Alessio (1993) regarding financial assets, and Cannari and D'Alessio (1990) on dwellings.

20 The method is as follows: 1 ) design weights are adjusted in order to account for the different rate of survey participation, as stated in D'Alessio and Faiella (2002); 2) data on financial assets are corrected as proposed in Cannari et al. (1990) and Cannari and D'Alessio (1993); 3) data on non-residential dwellings owned by households are corrected following a method originally proposed by Cannari and D'Alessio (1990) and subsequently refined by Brandolini et al. (2004).

21 These adjusted values are closer to the macroeconomic ones, although there are still some differences mainly due to heterogeneity in definitions and in classification rules. On these aspects see Brandolini et al. (2004).

22 These variations have been adjusted using the national average price changes for houses, as gathered from the survey (net of refurbishing expenses), with the twofold aim of accounting for the differences in prices between large municipalities and other towns and of aligning average revalued wealth with wealth reported by households. Furthermore, we assume that all the dwellings are located where the household head resides.

23 On the evaluation of capital gains for goods without a secondary market see Hendershott and Peek (1985).

24 In the survey, the value of firms is computed net of the value of buildings and land used in productive activity, which are instead treated as components of real household wealth. 
Figure 2

Shares of net wealth components, 2004: a comparison between adjusted and unadjusted data

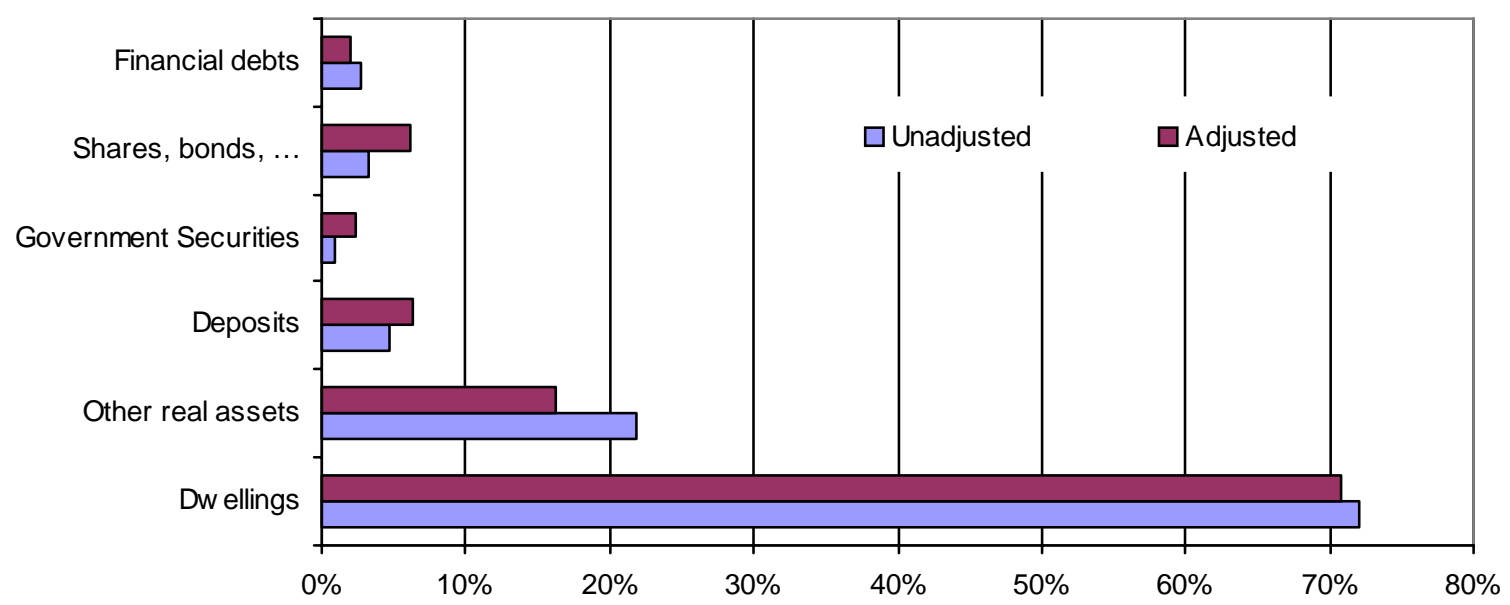

Authors' calculations on data from the Bank of Italy's SHIW Historical Database.

Capital gains are calculated for all assets involving share ownership ${ }^{25}$ using the MIB historical index.

Capital gains for a given class of fixed-interest financial assets or liabilities are generated by interest rate changes applying to items in that class. ${ }^{26}$ An increase in interest rates on the newly issued assets causes a fall in the value of assets already in circulation. Conversely, a rate cut for fixed-income assets produces a positive capital gain for the owner of assets of the same kind. In the same way, but with opposite signs, variations in passive rates generate capital gains for households with fixed-rate mortgages. The impact of changes in rates is higher the longer the time to maturity of the assets held. ${ }^{27}$

Referring to the definition adopted here, deposits and bonds (private and public) with variable interest rates have zero nominal capital gains, and therefore bear capital losses proportional to the inflation rate.

To evaluate the incidence of capital gains on wealth we adopt the Laspeyres index logic. Starting from survey data we estimate the (counterfactual) level of wealth that would have been yielded by capital gains only. In other words, we exclude savings, transfers and other variations caused by changes in the composition of household portfolios. Calculations are conducted both using 1989 as starting year and estimating chain indexes based on pairs of surveys. In the first case wealth composition is fixed at 1989, while in the second it varies between surveys. Of course, results based on chain indexes are closer to reality as they

25 This class also includes equity investment funds, whose incidence in total investment funds was estimated based on the data collected in the 2004 survey. Managed savings are regarded as investment fund savings.

26 In the case of fixed-income assets, we employed the average gross revenue of BTPs (Buoni del Tesoro Pluriennali, i.e. treasury bills with a time to maturity longer than one year), estimated on bonds with an outstanding time to maturity in excess of one year. For debts, we used the interest rate series on medium-term and long-term loans calculated by Casolaro, Gambacorta and Gobbi (2004). Finally, the time to maturity for mortgages was estimated using SHIW data, and time to maturity for fixed-income assets was estimated based on time to maturity of BTPs (Bank of Italy, Base Informativa Pubblica on line).

27 The series used to calculate wealth (price indexes, interest rates, time to maturity) are presented in Appendix A. 
account for the evolution in household portfolios. Therefore, comparing these indexes can be useful for evaluating the effects of changes in portfolio composition on capital gains. In order to simplify the comparison of results, all the wealth components, reconstructed with the methodology described above, are evaluated at 2004 prices, using the consumer price index.

\section{Capital gains in Italy according to SHIW data}

\section{Capital gains in 1989-2004}

SHIW data show that between 1989 and 2004 nominal per capita wealth more than doubled, from $€ 42,000$ to $€ 129,000$ (Table 1). Per capita wealth, reconstructed from the composition of household portfolios in 1989 applying the relevant price variation to each asset, was equal to $€ 95,000$; total capital gains thus equalled 60 per cent of the variation in nominal wealth. Savings, transfers and other effects due to portfolio reallocation explain the remaining 40 per cent. ${ }^{28}$

\section{Table 1}

\section{Per capita wealth variation and capital gains, 1989-2004}

Euros, percentages

\begin{tabular}{l|c}
\hline \multicolumn{1}{c|}{ Variables } & Average \\
\hline (a) 1989 wealth at 1989 prices & 42,503 \\
(b) 1989 wealth evaluated at 2004 prices using the consumer price index & 72,086 \\
(c) 1989 wealth evaluated at 2004 prices using asset price variations & 95,181 \\
(d) 2004 wealth evaluated at current prices & 129,408 \\
(e) $=($ c $)-($ a $)$ Total capital gains & 52,678 \\
(f) $=(c)-(b)$ Real capital gains & 23,095 \\
(g) $=[(d) /(b)-1]^{\star} 100$ Percentage increase in real wealth & 79.5 \\
(h) $=(f) /[(d)-(b)]^{\star} 100$ Percentage contribution of real capital gains to wealth & 40.3 \\
increase & 43.6 \\
(i) Percentage contribution of real capital gains to wealth increase, calculated & \\
with chain indexes & \\
\hline
\end{tabular}

Authors' calculations on data from the Bank of Italy's SHIW Historical Database.

This comparison does not account for the variations in the general price index. Evaluating all figures at 2004 prices, the average per capita wealth in the period 1989-2004 rose by about 70 per cent in real terms, from $€ 72,000$ to $€ 129,000$. More than 40 per cent of this increase was due to real capital gains.

28 We refer to per capita wealth in order to control for variations in household size and in the total number of households. 
When using chain indexes, the contribution of capital gains to wealth variation does not change much. In this case, per capita wealth variations are estimated for each pair of consecutive surveys, keeping the portfolio composition observed in the first survey fixed. Finally, these results are summed over the entire period. There are no substantial differences between the results based on the two different indexes (1989-based and chain) because a large share of capital gains comes from the growth in house prices, and this wealth component is not subject to frequent reallocation due to the high transaction costs.

Overall, survey data and NA yield similar results: the contribution of capital gains to wealth variation is always positive with an exception, i.e. the sub-period 1993-95, when the real prices of dwellings decreased (Figure 3).

Figure 3

\section{Real capital gains, 1989-2004}

Percentages of real wealth

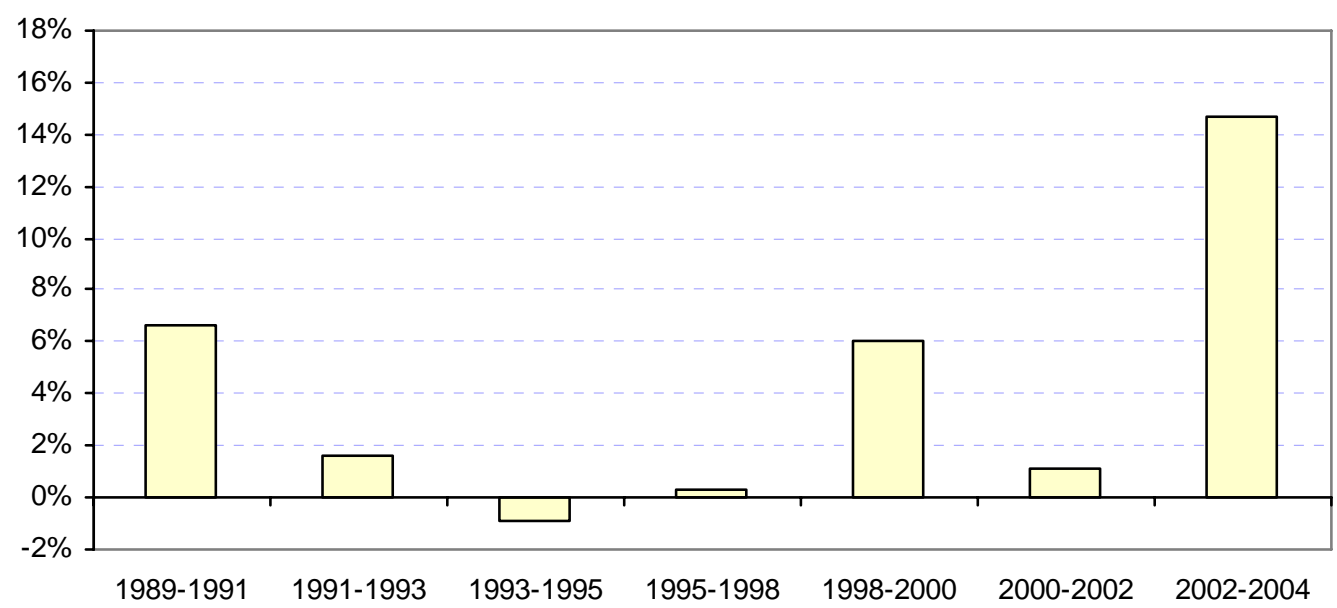

Authors' calculations on data from the Bank of Italy's SHIW Historical Database.

Table 2 shows that in 1989-2004 real capital gains were mainly influenced by the rise in house prices, averaging $€ 28,000$ or 63.8 per cent of total wealth held in this type of asset in 1989. Conversely, other assets such as deposits generated capital losses. During the period, the contribution of other wealth components to wealth variation was negligible. In particular, capital gains accruing to shares, although sizeable compared with the amount of wealth held in shares, represented only 1 per cent of total capital gains ( $€ 226$ out of $€ 23,096$ ).

The analysis of capital gains during individual sub-periods reveals that the contribution of shares was more significant between 1995 and 2002, with a positive sign between 1995 and 2000 and a negative sign between 2000 and 2002. The contribution of land and firms is very small and with changing signs. Fixed-income assets generate only small capital gains on average, with the exception of 1995-1998 when these assets generated €232 of per capita capital gains. The variation in mortgage interest rates also produced few capital gains: the largest amount was between 1995 and 1998, with a per capita capital loss of €88. 
Table 2

\section{Per capita real capital gains by source, 1989-2004}

Euros, 2004 prices, percentages of wealth amounts of the same category

\begin{tabular}{|c|c|c|c|c|c|c|c|c|c|c|}
\hline $\begin{array}{l}\text { Capital gain } \\
\text { source }\end{array}$ & $\begin{array}{l}1989- \\
1991\end{array}$ & $\begin{array}{l}1991- \\
1993\end{array}$ & $\begin{array}{l}1993- \\
1995\end{array}$ & $\begin{array}{l}1995- \\
1998\end{array}$ & $\begin{array}{l}1998- \\
2000\end{array}$ & $\begin{array}{l}2000- \\
2002\end{array}$ & $\begin{array}{l}2002- \\
2004\end{array}$ & $\begin{array}{c}\text { Total } \\
1989- \\
2004\end{array}$ & $\begin{array}{c}\text { 1989- } \\
2004 \\
\text { Index }^{1}\end{array}$ & $\begin{array}{c}\text { 1989- } \\
2004 \\
\text { Chain } \\
\text { index }^{1}\end{array}$ \\
\hline Dwellings & 6395 & 2512 & 394 & -1356 & 4406 & 5240 & 17356 & 28147 & 63.8 & 71.7 \\
\hline Land & -56 & -151 & -74 & -5 & 69 & 14 & 20 & -181 & -8.4 & -8.4 \\
\hline Firms & 111 & -57 & -213 & -88 & -9 & 10 & 13 & -113 & -2.4 & -2.4 \\
\hline $\begin{array}{l}\text { Bonds and } \\
\text { BTPs }\end{array}$ & -61 & -22 & -69 & 232 & -103 & 9 & 5 & -157 & -31.1 & -15.4 \\
\hline Share & -271 & -147 & 97 & 2474 & 2626 & -2976 & -48 & 226 & 20.6 & 20.6 \\
\hline $\begin{array}{l}\text { Fixed rate } \\
\text { mortgages }\end{array}$ & 28 & 39 & 38 & -88 & -3 & 11 & 7 & -43 & -18.1 & 8.7 \\
\hline Other assets & -1368 & -977 & -979 & -889 & -784 & -1072 & -456 & -4868 & -40.9 & -37.0 \\
\hline Net wealth & 4779 & 1196 & -805 & 280 & 6202 & 1236 & 16544 & 23096 & 32.0 & 32.3 \\
\hline
\end{tabular}

${ }^{1}$ Percentage of wealth variation due to capital gains for each asset.

Authors' calculations on data from the Bank of Italy's SHIW Historical Database.

\section{Distribution and concentration of wealth and capital gains}

To evaluate the contribution of capital gains to wealth distribution we consider how these gains were distributed in 1989-2004 among the different wealth classes. ${ }^{29}$

Chain indexes, calculated on per capita wealth, show that the contribution of capital gains to wealth variations increases with wealth itself (Table B.1). This happens because over the period the prices of some assets, such as dwellings and shares, grew on average more than the inflation rate, so that the rich families that owned these assets received higher capital gains than the rest. On the other hand, other wealth components, such as deposits, generated negative capital gains equal to the inflation rate. Thus, households with lower wealth, typically holding mainly this kind of asset, did not gain from price variations (Table B.3).

Capital gains measured with chain indexes show a clear dependence on education: households headed by university graduates have higher capital gains than households whose head has a lower level of education. This result can be due to several factors: a portfolio composition favouring assets, whose prices grew more in the period owing to lower risk aversion and/or higher levels of wealth of more educated households; greater ability on the part of families whose head has a high level of education to change their portfolio composition to include broad categories of assets with higher capital gains; more success in forecasting the price changes of single assets. Survey data provide us with unequivocal evidence that risk preferences differ considerably across individuals and that these

29 See Table B.1 in Appendix B for the total effect of capital gains in 1989-2004, and Tables B.2 and B.3 for a breakdown of capital gains by sub-period, source and wealth class. 
differences have substantial explanatory power with respect to individual decisions. Guiso and Paiella (2005) show, for instance, that the risk-averse tend to invest less in education and are significantly less wealthy than the risk-prone; preferring less variable earnings, riskaverse individuals end up, on average, with lower capital gains. We also find that, in the case of more educated households, the estimates of capital gains based on the chain index are greater than the estimates based on the 1989 wealth composition; on the contrary, the chain index is lower than the fixed-base index for less educated households. This result suggests that educated households are better able to switch their portfolio composition towards more profitable assets than less educated households. Educated households, however, do not seem good at forecasting the future performance of single assets (we will consider this issue in the following sections). While education may help in assessing whether a whole market (i.e., the housing market or the stock market) is likely to be overvalued or undervalued at a particular time, it is less useful in helping households to predict, for instance, the price change of the shares of a single corporation.

Where age is concerned, chain indexes indicate that households whose heads are older reaped smaller benefits from capital gains, probably due to their lower propensity to risk, which generates portfolios that are less sensitive to price variations.

As far as place of residence is concerned, households living in the South or in large cities obtained fewer capital gains over the observed period. This result is mainly due to the fact that in 1993-99 house prices in large cities dropped more than house prices in smaller cities (where prices had grown less during the previous market cycle). In the following years, the trend changed and prices of dwellings grew more in large cities, producing higher capital gains for resident households (Table B.2).

Summing up, capital gains have an important role in explaining wealth variations and produce a differential effect among the various household categories. It is therefore interesting to evaluate the influence of capital gains on inequality and on the inter-temporal mobility of households between wealth classes.

In order to verify the effect of capital gains on wealth distribution we construct a measure of revalued wealth for each year, applying to each asset its price variation. We then estimate the Gini concentration index on this measure. These calculations are made for the whole period of analysis. For each survey we obtain a series of wealth concentration indexes calculated from the portfolio composition of each year and applying asset price variations in the different periods (Figure 4). We can then evaluate the change in wealth concentration over time after the variation in asset prices, given the portfolio composition and the wealth level of the base year. During the period, and in particular up to 2000, the concentration indexes show a clear upward trend, confirming the importance of capital gains in the growth of wealth concentration.

Results obtained so far do not consider changes in household portfolios over time. In order to account for this aspect, we compare the concentration indexes of nominal wealth with the ones estimated on wealth at 2004 constant prices. The bottom dotted line in Figure 4 represents the indexes calculated for each survey using current prices, while the top dotted line refers to concentration indexes calculated with constant prices. The distance between the two lines becomes wider in earlier years; in other words, wealth concentration measured at constant prices tends to be larger than the one measured using current prices, especially during the first part of the period. Between 1989 and 2004 the Gini concentration index rises by 3.9 percentage points; if asset prices are held constant, the increase drops to 2.4 points. 
We can therefore conclude that the variation in asset prices contributed to the increase in concentration. ${ }^{30}$

Analysing Figure 4 we also observe that concentration indexes calculated holding portfolio composition constant (continuous lines) are more stable than the other ones (dotted lines). The differences are due to wealth reallocation, the influence of savings on wealth variation (which is not included in the estimation obtained holding portfolio composition constant), and survey sampling factors (sample composition varies across waves, on account of changes in target population and sampling variability).

Figure 4

Gini's index for reconstructed and
actual net per capita wealth 1989-2004

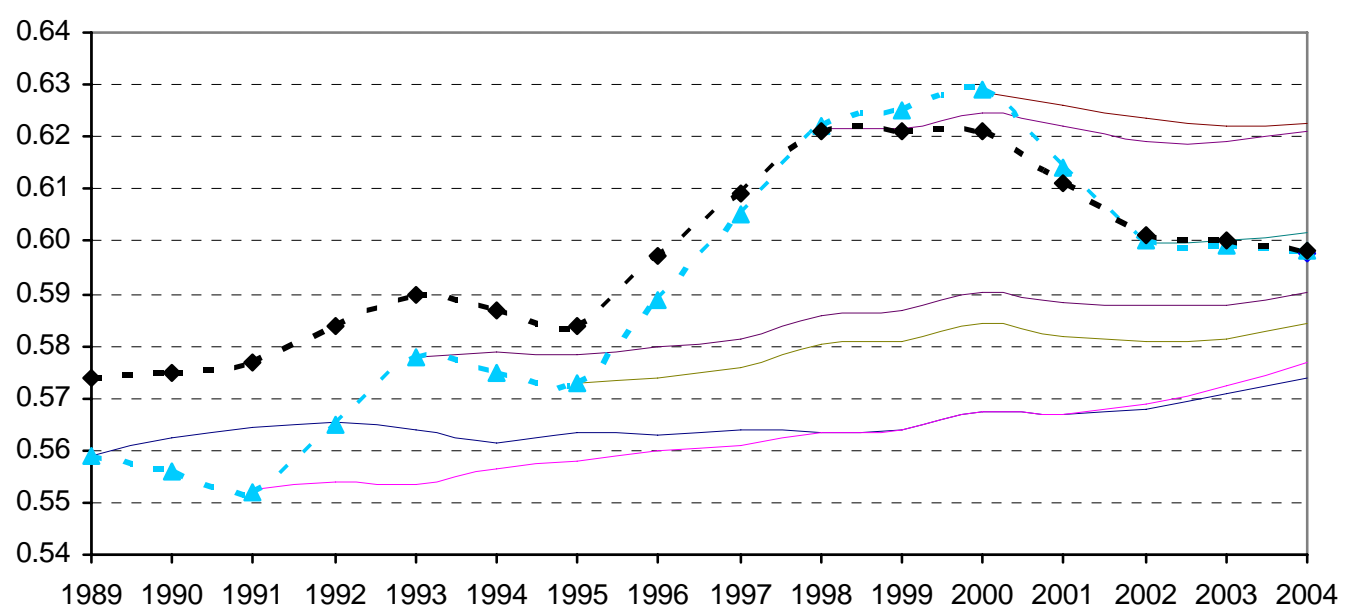

Authors' calculations on data from the Bank of Italy's SHIW Historical Database.

\section{Inter-temporal mobility and capital gains}

In this section we study the impact of capital gains on the inter-temporal mobility of households between wealth classes. This aspect is not necessarily linked to the previous ones: changes in wealth distribution and concentration do not necessarily imply mobility, and vice versa. For example, if capital gains are a non-negative monotonic function of wealth they affect concentration, but they do not generate mobility; conversely, if all rich households suffer heavy capital losses (becoming poor) while all poor households enjoy large capital gains (becoming rich), the mobility induced by price variability is very high, but the distribution and the concentration of wealth may remain unchanged.

The analysis is conducted by revaluing assets held in the base year using price variations occurring during the period. Results obtained with this method should be interpreted with caution as they are based on the hypothesis that no portfolio reallocation occurs between

30 These estimates indicate that more than one-third of the growth in concentration is due to price variations. This result must be interpreted with some caution as we do not take into account the fact that households with positive capital gains should increase their consumption and reduce their savings, partially offsetting concentration growth (and vice versa in the case of capital losses). The magnitude of the variations in consumption of each individual depends both on the perception of the persistence of price variation and on his expected residual life. 
survey waves. On the other hand, it should be noted that Italian households mainly hold wealth in the form of dwellings, which are seldom an object of reallocation due to the high transaction costs.

The share of panel households that move across wealth classes (defined as wealth quintiles) between one survey and the next is on average 46 per cent (Table 3); 5 to 10 per cent of families change wealth classes as a result of capital gains. The comparison of this result with the transitions actually observed on panel households shows that capital gains explain on average 15.5 per cent of observed transitions.

Table 3

Transition between net wealth quintiles, 1989-2004

Percentage of households

\begin{tabular}{l|c|c|c}
\hline Period & $\begin{array}{c}\text { Transitions due to } \\
\text { capital gains }\end{array}$ & $\begin{array}{c}\text { Transitions } \\
\text { estimated on panel } \\
\text { data }\end{array}$ & $\begin{array}{c}\text { Contribution of } \\
\text { capital gains }\end{array}$ \\
\hline $1989-1991$ & 9.4 & 47.6 & 19.7 \\
$1991-1993$ & 7.4 & 50.3 & 14.8 \\
$1993-1995$ & 6.2 & 40.4 & 15.3 \\
$1995-1998$ & 7.6 & 46.5 & 16.3 \\
$1998-2000$ & 5.0 & 46.5 & 10.8 \\
$2000-2002$ & 5.9 & 43.7 & 13.6 \\
$2002-2004$ & 7.9 & 44.1 & 18.0 \\
Average & 7.1 & 45.6 & 15.5 \\
\hline
\end{tabular}

Authors' calculations on data from the Bank of Italy's SHIW Historical Database.

Considering that transitions among the panel component of the sample are probably overestimated due to measurement error, the impact of capital gains on wealth mobility is probably underestimated. On the whole, capital gains seem to be an important source of inter-temporal mobility among wealth classes, at least when considering periods of 2 or 3 years. Over a longer horizon, the share of families that change wealth class as a result of capital gains rises, although the increase is less than proportional to the increase in period length: as a consequence of asset price variation, between 1989 and 2004 some 17.9 per cent of families changed wealth class. This happened because a share of the wealth mobility induced by capital gains in short periods is absorbed during the longer intervals, simply reflecting a component of volatility in asset prices.

\section{The role of capital gains in wealth dynamics}

In this section we evaluate the contribution of capital gains to household wealth dynamics with respect to the other wealth components (see equation 1), savings and transfers between families (gifts and bequests). 
Table 4

Variance decomposition of wealth variations, 1993-2002

Percentages

\begin{tabular}{|c|c|c|c|c|c|}
\hline & Factor & 1993 & 1995 & 1998 & 2000 \\
\hline \multirow[t]{4}{*}{1995} & Capital gains & 40.9 & & & \\
\hline & Savings & 43.6 & & & \\
\hline & Received transfers & 0.5 & & & \\
\hline & Given transfers (-) & 14.9 & & & \\
\hline \multirow[t]{4}{*}{1998} & Capital gains & 29.9 & 28.2 & & \\
\hline & Savings & 40.3 & 33.8 & & \\
\hline & Received transfers & 27.8 & 37.6 & & \\
\hline & Given transfers (-) & 2.0 & 0.4 & & \\
\hline \multirow[t]{4}{*}{2000} & Capital gains & 31.1 & 32.9 & 46.2 & \\
\hline & Savings & 47.8 & 40.6 & 48.7 & \\
\hline & Received transfers & 19.9 & 26.3 & 4.0 & \\
\hline & Given transfers (-) & 1.2 & 0.2 & 1.2 & \\
\hline \multirow[t]{4}{*}{2002} & Capital gains & 26.6 & 26.7 & 35.3 & 43.1 \\
\hline & Savings & 54.3 & 52.0 & 51.7 & 32.4 \\
\hline & Received transfers & 18.1 & 21.1 & 8.9 & 17.7 \\
\hline & Given transfers (-) & 1.1 & 0.2 & 4.2 & 6.8 \\
\hline Sample size ${ }^{1}$ & & 591 & 680 & 1,267 & 1,750 \\
\hline
\end{tabular}

${ }^{1}$ Panel households that answered to the 2002 monographic section (half of the sample). The number of families is thus equal for all the elements in the same column. The symbol (-) indicates that the component is negatively correlated to wealth variations.

Authors' calculations on data from the Bank of Italy's SHIW Historical Database.

For panel households, we considered both the wealth variations due to capital gains ${ }^{31}$ and those due to savings resulting from answers given in different waves (values are estimated for years between the waves); variations accruing to transfers were obtained from the 2002 monographic section, which provides retrospective information on this subject. ${ }^{32}$ The use of retrospective data gathered in 2002 does not allow the analysis to be extended to 2004 . Also, we cannot go back to the very start of the period because the number of panel households that stayed in the sample from 1989 to 2002 is too small. The analysis is carried out with respect to the sub-period 1993-2002.

31 We normally refer to real capital gains, net of inflation. All components are valued at constant prices.

32 In this experiment we refer to uncorrected wealth data, because adjustments do not account for the relations among the components considered here. Moreover, on the panel sample we calculate wealth as the sum of its components, rather than taking the raw observations. The difference between these two wealth measures is equal to a residual component due to many factors (measurement errors in the answer, incomplete definition of wealth, variations in household composition). 
For each year, the variance of wealth variations can be decomposed using the relation that links the variance of a total with the covariances of the total and its components (Shorrocks, 1983):

$\operatorname{Var}\left(\Delta W_{t}\right)=\operatorname{Cov}\left(S_{t}, \Delta W_{t}\right)+\operatorname{Cov}\left(T_{t}, \Delta W_{t}\right)+\operatorname{Cov}\left(C G_{t}, \Delta W_{t}\right)$

It is therefore possible to measure the relative contribution of each component through the following ratios:

$\operatorname{Cov}\left(S_{t}, \Delta W_{t}\right) / \operatorname{Var}\left(\Delta W_{t}\right) ; \operatorname{Cov}\left(T_{t}, \Delta W_{t}\right) / \operatorname{Var}\left(\Delta W_{t}\right) ; \operatorname{Cov}\left(C G_{t}, \Delta W_{t}\right) / \operatorname{Var}\left(\Delta W_{t}\right)$

In general, we observe that the contribution of capital gains to wealth variations is relevant and equal to about 35 per cent. Savings explain, on average, approximately 45 per cent of total variance, while net transfers explain about 20 per cent (Table 4).

The small size of some of the samples suggests that these results should be interpreted with caution, partly because the importance of each factor may well vary over time. We can nevertheless observe that for longer periods the contribution of savings increases while the contribution of capital gains decreases. The variance of wealth variation over ten years, between 1993 and 2002, is due for one fourth to capital gains, for more than one half to savings and for 20 per cent to transfers.

\section{Further considerations about price volatility}

All the analyses reported in the previous paragraphs have been conducted using average price variations for each asset; we neglected an important part of the volatility, which may be important in explaining the distributive role of capital gains. The price of a house in the city centre can vary in a different way from the price of a house in the suburbs; a family that holds stocks can obtain different capital gains compared with a household with a different portfolio composition. ${ }^{33}$

The variability of price indexes for dwellings and stocks, the wealth components that appear more important in determining capital gains, is quite high. Yearly variations of stock prices between 1990 and 2004 show a standard deviation of about 25 per cent; ${ }^{34}$ prices of houses per square metre show a standard deviation of yearly 1989-2004 variations (within provinces and types of municipalities) of about 7 per cent. ${ }^{35}$ It is therefore worth evaluating whether and to what extent this residual variability depends on household characteristics.

The monographic section of the 2002 wave asks households to evaluate capital gains (cashed and uncashed) on each asset they hold since it was bought. Based on these data, we study the link between stock price variations and household characteristics; we carry out two kinds of calculations. First we study the linear relation of capital gains, expressed as a percentage of the starting capital, with some characteristics of the head of household (gender, education and working status) and with geographical area of residence, population of the town of residence, family income and year of acquisition of the asset. In the second

33 According to survey data from the 1998 wave, households hold, on average, shares of 2.7 different companies. We do not have any further information about the specifics of these stocks.

34 The estimate refers to the yearly variations in prices of the individual stocks included in the Datastream database.

35 The variations in house prices between two survey waves, as declared by the owners, show a standard deviation of 20 to 25 per cent within a given province and type of municipality. Considering that the measurement error contained in survey data inflates variability (the Heise reliability index is equal to about 84 per cent; see Biancotti, D'Alessio and Neri, 2004), and taking into account the interval between surveys, we can estimate that owner-estimated yearly variations in house value per square metre have a standard deviation of about 7 per cent. 
exercise, the dependent variable is equal to one when there is a positive capital gain and to zero otherwise; we run a logistic regression model with the same independent variables used in the linear model. None of the variables turns out to be significant for any of the models; the sample dimensions are 500 and 700 units, respectively. The results of these calculations do not show the presence of any significant statistical relationship between capital gains and family income or education. This result is not surprising: a substantial body of literature on market efficiency points out that it is very difficult to obtain higher return on assets based only on publicly available information and individual forecasting abilities.

In order decide how to invest their money, three out of four Italian households consult professional agents (banks, post offices, securities firms), while 27 per cent rely on advice from relatives or friends. These results show that no substantial share of households benefits from better information than the rest; everyone relies on either standard formal sources of information or informal non-professional advice which is presumably not particularly efficient or reliable. ${ }^{36}$ Moreover, households appear to devote very little of their time to obtaining financial information. According to survey data for 2004, only 5 per cent of households holding financial assets spend more than one hour a week sourcing financial information, while more than 65 per cent do not spend any time at all doing so.

Where real assets are concerned, it is plausible that households normally do not own dwellings - in particular the house they reside in - for speculative reasons. We therefore expect the link between price variations and individual characteristics to be weak, partly because the estimates of house values already incorporate information on location (province and type of municipality) likely to affect the price.

These considerations suggest that for both stocks and dwellings variability around the average value is due to factors generally uncorrelated with observed socio-demographic household features. It is therefore possible to evaluate the impact of capital gains on wealth concentration and variability by simulating the wealth distributions obtained from the variation in average prices, and adding for each family a random element to account for residual variability. ${ }^{37}$

The introduction of this additional variability with respect to the case without random effects that we considered previously generates a slight increase in concentration levels. ${ }^{38} \mathrm{We}$ conclude that, during the observed period, the contribution of capital gains to the increase in wealth concentration is greater than the one found when omitting this component of variability. Furthermore, the introduction of a random effect increases the contribution of capital gains to transitions among wealth classes; on average, it rises from 15.5 to 19.9 per cent (Table 5). Similar results are found when repeating the exercise of variance decomposition carried out in Section 5.4; if capital gains are augmented by a random component reflected in wealth variation, the share of variability accruing to them increases.

36 The data show that only 4 per cent of the households who invest in financial assets are assisted by experts, while 3 per cent decide how to invest based on suggestions offered by the specialised press.

37 This random component is drawn from a normal distribution with zero mean and standard deviation equal to the one estimated for each of the price variations and then added to the corresponding average. For houses, the estimated yearly standard deviation is 7 per cent. For stocks, we assume that each household owns shares in 2.7 different companies (the average value observed in 1998, the last year for which this information is available), and that the companies are randomly selected. The correspondent standard deviation is about 15 per cent.

38 Should the random component be positively correlated with the amount of wealth, the effect on wealth would be stronger. 
Table 5

\section{Variability effect on households' transitions between net wealth fifths, 1989-2004}

Percentages of households

\begin{tabular}{l|c|c|c|c|c}
\hline Period & $\begin{array}{c}\text { Transitions due } \\
\text { to capital } \\
\text { gains, without } \\
\text { random effects }\end{array}$ & $\begin{array}{c}\text { Transitions due } \\
\text { to capital } \\
\text { gains, with } \\
\text { random effects }\end{array}$ & $\begin{array}{c}\text { Transitions } \\
\text { estimated on } \\
\text { panel } \\
\text { households }\end{array}$ & $\begin{array}{c}\text { Contribution of } \\
\text { capital gains } \\
\text { without } \\
\text { random effects }\end{array}$ & $\begin{array}{c}\text { Contribution } \\
\text { of capital } \\
\text { gains, with } \\
\text { random } \\
\text { effects }\end{array}$ \\
\hline $1989-1991$ & 9.4 & 10.4 & 47.6 & 19.7 & 21.9 \\
$1991-1993$ & 7.4 & 9.5 & 50.3 & 14.8 & 18.9 \\
$1993-1995$ & 6.2 & 8.7 & 40.4 & 15.3 & 21.4 \\
$1995-1998$ & 7.6 & 10.1 & 46.5 & 16.3 & 21.7 \\
$1998-2000$ & 5.0 & 7.2 & 46.5 & 10.8 & 15.4 \\
$2000-2002$ & 5.9 & 8.5 & 43.7 & 13.6 & 19.5 \\
$2002-2004$ & 7.9 & 9.1 & 44.1 & 18.0 & 20.6 \\
Average & 7.1 & 9.1 & 45.6 & 15.5 & 19.9 \\
\hline
\end{tabular}

Authors' calculations on data from the Bank of Italy's SHIW Historical Database.

\section{Conclusions}

This paper analyses the influence of capital gains on wealth distribution and growth over the period 1989-2004. Estimates were obtained using different data sources.

The main results can be summarised as follows:

- macroeconomic estimates show that between 1989 and 2004 the net wealth of households (valued at 2004 prices using the consumer price index for the whole nation) increased by $€ 3,573$ billion, from $€ 4,712$ billion to $€ 8,285$ billion. In 1990 2004 , total household net saving amounted to $€ 1,920$ billion, equal to 53.7 per cent of wealth variation. Over the same period, the contribution of capital gains to total household wealth variation was about 50 per cent;

- $\quad$ between 1990 and 2004, capital gains averaged around 12.6 per cent of household disposable income (which does not include them), while capital income amounted to 32.1 per cent. Total revenue from wealth, including capital gains, is one-third larger than when considering capital income only. It is worth noting that capital gains are highly variable over time and that during half of the observed period they were larger in absolute value than one-fifth of disposable income; in 2002-2004 the sum of capital gains was equal to disposable income in 2004;

- $\quad$ analysing SHIW data, we obtained results qualitatively similar to the NA: between 1989 and 2004, the contribution of capital gains to per capita wealth variation was about 40 per cent in real terms;

- between 1989 and 2004, the Gini concentration index for wealth increased by 3.9 percentage points; if we hold asset prices constant, the increase is 2.4 points. Asset price variation explains more than one-third of wealth concentration dynamics; 
- $\quad$ on average capital gains are more than proportionally higher for wealthier families; the effects on concentration are driven by price variations in houses and stocks;

- $\quad$ considering panel survey data, about 46 per cent of families change wealth class (classes are defined by wealth quintiles) between two subsequent surveys. Between 5 and 10 per cent of households change class due to capital gains. Capital gains explain, on average, $\mathbf{1 5 . 5}$ per cent of the actual transitions among wealth classes;

- $\quad$ if we consider a wider time span when observing transitions, the share of households that changes wealth class as a result of capital gains increases, although less than proportionally to variations in the length of the reference period: between 1989 and 2004, 19 per cent of the families changed wealth class on account of asset price variations. A portion of the short-run mobility due to capital gains is absorbed over longer intervals, simply reflecting a component of volatility in asset prices;

- $\quad$ using panel data to evaluate the relative importance of capital gains with respect to both savings and transfers, we find that about one-third of wealth dynamics is explained by capital gains, 45 per cent by savings, and 20 per cent by transfers;

- $\quad$ simulations that account for the variance of each asset price around an average value calculated on a homogenous group of assets of the same kind (for example, the variance of stock prices for a single company compared with the MIB index), suggest that the contribution of capital gains to the growth in concentration and to transitions between wealth classes is probably greater than the one estimated using only average price indexes for each kind of asset. 


\section{Appendix A: \\ Data on asset prices}

Figure A.1

\section{Variations of house prices per square metre} and of stock prices, 1990-2004

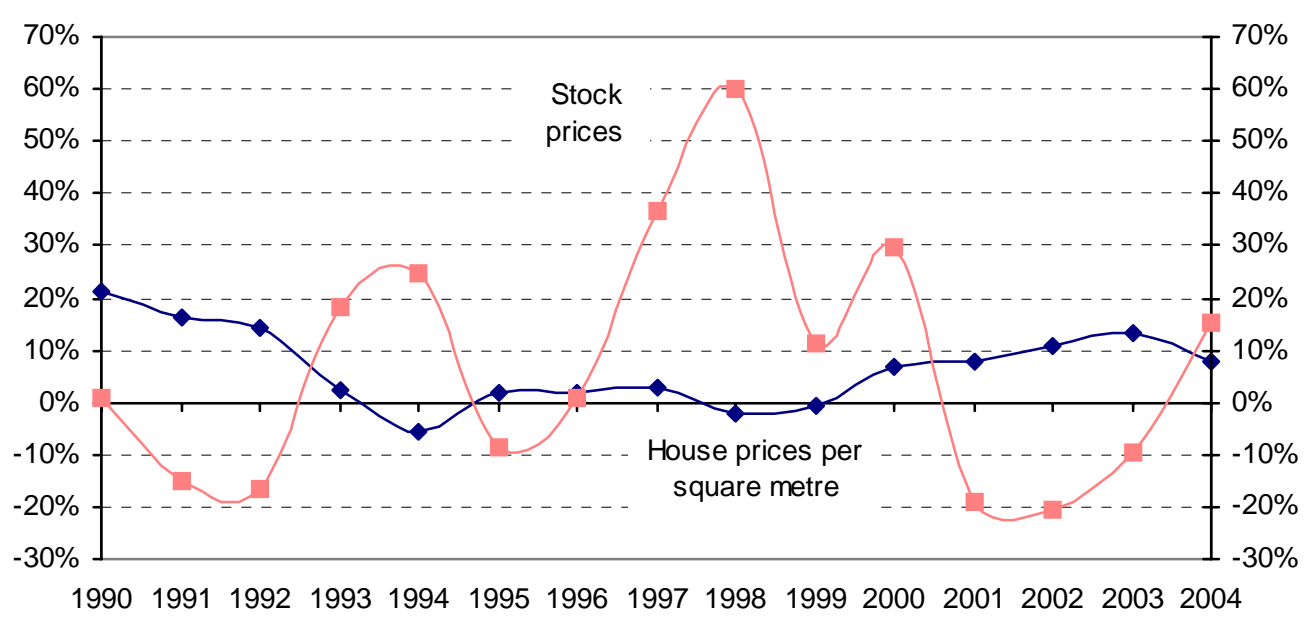

Source: Stock price index MIB30 (Italian Stock Exchange); value of houses per square metre (calculations based on Muzzicato, Sabbatini and Zollino, 2002).

Figure A.2

Variations of fixed capital goods (excluding construction) prices and of land prices, 1990-2004

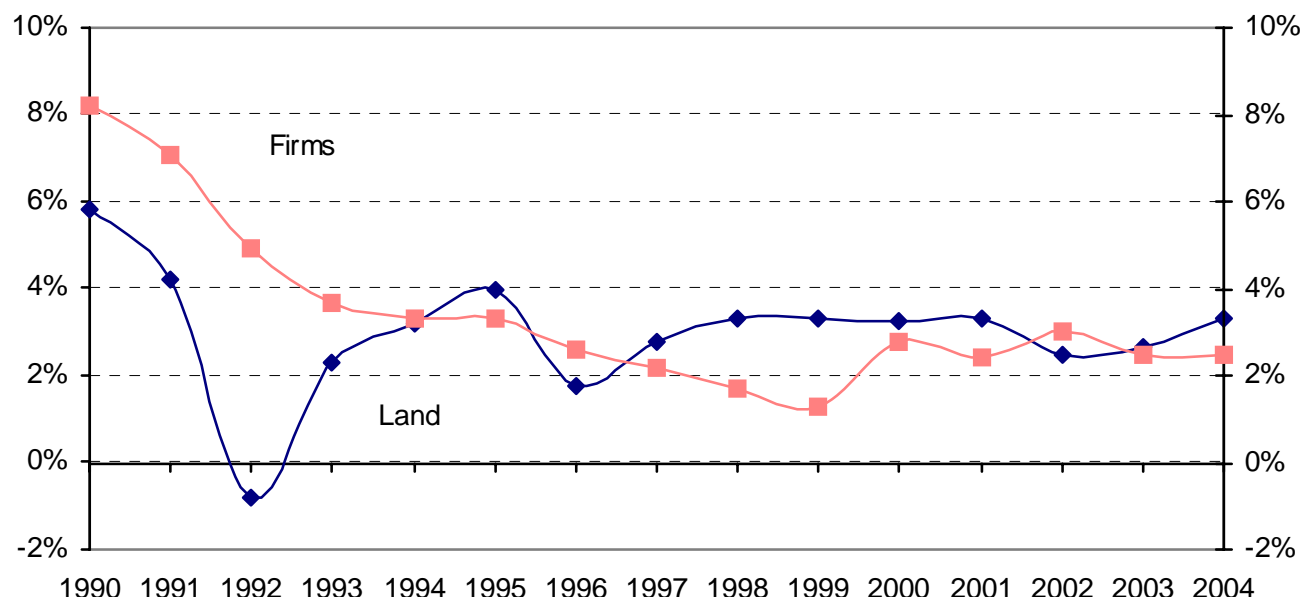

Source: Land price index (Povellato, 1997). Fixed capital stock (excluding construction) deflator (Istat). 
Figure A.3

\section{Interest rates and average time to maturity of BTPS and of fixed rate mortgages, 1989-2004}

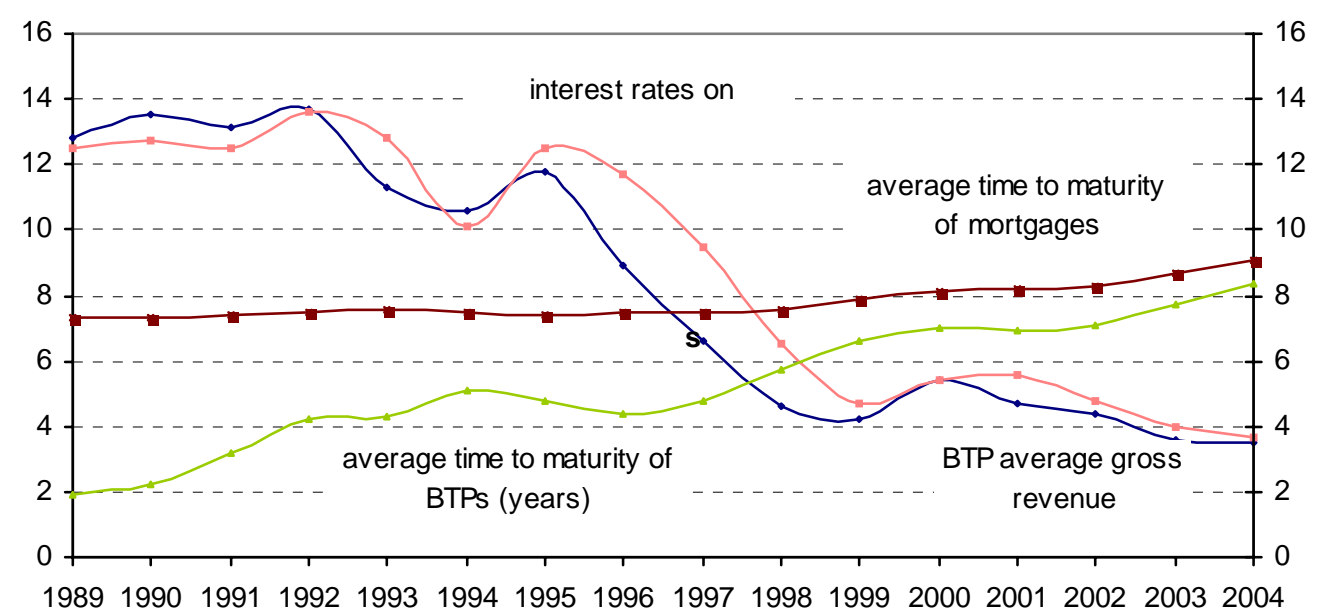

Source: BTP average gross revenue (for bonds expiring after one year): bonds quoted on the Italian Stock Exchange (Bank of Italy, Base Informativa Pubblica on line). Time to maturity of BTPs listed on M.T.S. (Bank of Italy, Base Informativa Pubblica on line). Average time to maturity of mortgages (calculations on SHIW data between 1995 and 2004, under the hypothesis that the mortgage was obtained during the year of acquisition of the house. Data on mortgage time to maturity has been estimated for years preceding 1995). Interest rate on consumer loans, medium-term to long-term (calculated by Casolaro, Gambacorta and Gobbi, 2004). 
Appendix B:

Statistical tables

Table B.1

Wealth increase and real capital gains between 1989 and 2004

Percentages

\begin{tabular}{|c|c|c|c|}
\hline & $\begin{array}{c}\text { Per capita } \\
\text { wealth growth } \\
\text { between } 1989 \\
\text { and } 2004\end{array}$ & $\begin{array}{l}\text { Capital gains } \\
\text { between } 1989 \\
\text { and } 2004 \text { on per } \\
\text { capita wealth }\end{array}$ & $\begin{array}{l}\text { Capital gains } \\
\text { between } 1989 \\
\text { and } 2004 \text { on per } \\
\text { capita wealth } \\
\text { (chain indexes) }\end{array}$ \\
\hline \multicolumn{4}{|l|}{ Gender } \\
\hline male & 72.3 & 32.7 & 33.4 \\
\hline female & 79.6 & 29.8 & 28.5 \\
\hline \multicolumn{4}{|l|}{ Age } \\
\hline up to 30 & 28.2 & 32.8 & 41.1 \\
\hline $31-40$ & 65.9 & 33.6 & 37.5 \\
\hline $41-50$ & 70.0 & 35.1 & 35.0 \\
\hline $51-65$ & 55.2 & 30.8 & 32.4 \\
\hline over 65 & 98.1 & 27.5 & 22.3 \\
\hline \multicolumn{4}{|l|}{ Education } \\
\hline none & 72.5 & 28.7 & 21.7 \\
\hline elementary school & 68.5 & 32.5 & 25.5 \\
\hline middle school & 45.2 & 31.2 & 29.9 \\
\hline high school & 67.5 & 33.3 & 35.1 \\
\hline university & 82.9 & 31.0 & 37.2 \\
\hline \multicolumn{4}{|l|}{ Work status } \\
\hline employee & 48.9 & 36.7 & 40.5 \\
\hline self-employed & 82.9 & 28.2 & 33.1 \\
\hline not employed & 90.1 & 29.2 & 22.2 \\
\hline \multicolumn{4}{|l|}{ Wealth fifth ${ }^{1}$} \\
\hline I fifth & 21.5 & -7.3 & -7.0 \\
\hline II fifth & 57.9 & 22.9 & 20.6 \\
\hline III fifth & 81.6 & 34.9 & 38.6 \\
\hline IV fifth & 79.5 & 35.4 & 35.0 \\
\hline$\vee$ fifth & 84.3 & 32.4 & 32.1 \\
\hline
\end{tabular}




\section{Table B.1 (cont)}

\section{Wealth increase and real capital gains}

between 1989 and 2004

Percentages

\begin{tabular}{l|c|c|c}
\hline & $\begin{array}{c}\text { Per capita } \\
\text { wealth growth } \\
\text { between 1989 } \\
\text { and 2004 }\end{array}$ & $\begin{array}{c}\text { Capital gains } \\
\text { between 1989 } \\
\text { and 2004 on per } \\
\text { capita wealth }\end{array}$ & $\begin{array}{c}\text { Capital gains } \\
\text { between 1989 } \\
\text { and 2004 on per } \\
\text { capita wealth } \\
\text { (chain indexes) }\end{array}$ \\
\hline Town size & 72.0 & 35.0 & 34.8 \\
up to 20,000 inhabitants & 116.6 & 33.9 & 35.9 \\
$20,000-40,000$ & 88.4 & 29.9 & 31.2 \\
$40,000-500,000$ & 37.6 & 27.8 & 21.0 \\
more than 500,000 & 76.8 & 32.1 & 34.6 \\
Geographical area & 100.9 & 39.4 & 34.9 \\
North & 43.2 & 26.1 & 24.0 \\
Centre & 74.2 & 32.0 & 32.3 \\
$\quad$ South and Islands & & & \\
Total & & & \\
\hline
\end{tabular}

Authors' calculations on data from the Bank of Italy's SHIW Historical Database. 
Table B.2

Real capital gains between 1989 and 2004

Percentages

\begin{tabular}{|c|c|c|c|c|c|c|c|c|}
\hline & & apital $\mathbf{g}$ & ins as & share 0 & per ca & ta weal & & Chain \\
\hline & $\begin{array}{l}1989 \\
1991\end{array}$ & $\begin{array}{l}1991 \\
1993\end{array}$ & $\begin{array}{l}1993 \\
1995\end{array}$ & $\begin{array}{l}1995 \\
1998\end{array}$ & $\begin{array}{l}1998 \\
2000\end{array}$ & $\begin{array}{l}2000 \\
2002\end{array}$ & $\begin{array}{l}2002 \\
2004\end{array}$ & $\begin{array}{l}1989 \\
2004\end{array}$ \\
\hline Gender & & & & & & & & \\
\hline male & 6.9 & 2.0 & -1.0 & 0.4 & 6.1 & 0.9 & 14.9 & 33.4 \\
\hline female & 5.6 & -0.2 & -0.8 & 0.0 & 5.9 & 1.9 & 14.0 & 28.5 \\
\hline Age & & & & & & & & \\
\hline up to 30 & 8.1 & 3.5 & -1.3 & -0.4 & 6.3 & 4.0 & 16.0 & 41.1 \\
\hline $31-40$ & 7.7 & 1.1 & -0.1 & -0.6 & 4.8 & 3.9 & 16.8 & 37.5 \\
\hline $41-50$ & 8.1 & 2.6 & -1.1 & -1.4 & 6.1 & 2.3 & 14.9 & 35.0 \\
\hline $51-65$ & 6.1 & 0.8 & -0.9 & 0.4 & 5.7 & 1.8 & 15.6 & 32.4 \\
\hline over 65 & 2.8 & 0.3 & -1.5 & 2.9 & 6.8 & -2.0 & 11.7 & 22.3 \\
\hline Education & & & & & & & & \\
\hline none & 5.2 & 0.6 & -0.4 & 0.1 & 4.8 & -0.4 & 10.5 & 21.7 \\
\hline elementary school & 5.0 & 1.5 & -0.6 & -0.9 & 5.5 & 0.4 & 12.8 & 25.5 \\
\hline middle school & 6.0 & 1.9 & -0.4 & -0.8 & 5.4 & 1.9 & 13.2 & 29.9 \\
\hline high school & 7.7 & 1.6 & -1.1 & 0.0 & 6.1 & 2.1 & 15.2 & 35.1 \\
\hline university & 7.6 & 1.0 & -1.8 & 3.3 & 7.0 & -0.1 & 16.5 & 37.2 \\
\hline Work status & & & & & & & & \\
\hline employee & 8.0 & 2.1 & -0.8 & -0.7 & 6.4 & 3.5 & 17.5 & 40.5 \\
\hline self-employed & 6.5 & 2.2 & -0.6 & 1.0 & 5.5 & 1.6 & 13.5 & 33.1 \\
\hline Not employed & 4.0 & -0.3 & -1.5 & 0.9 & 6.1 & -1.0 & 12.8 & 22.2 \\
\hline Wealth fifth & & & & & & & & \\
\hline I fifth & -2.9 & -1.3 & -1.2 & -2.2 & -0.4 & -1.7 & 2.6 & -7.0 \\
\hline II fifth & 4.1 & -0.2 & -1.5 & -0.5 & 4.2 & 1.1 & 12.5 & 20.6 \\
\hline III fifth & 7.2 & 2.6 & 0.0 & -0.9 & 5.8 & 3.8 & 15.7 & 38.6 \\
\hline IV fifth & 6.6 & 2.4 & -0.9 & -1.9 & 5.7 & 3.3 & 16.5 & 35.0 \\
\hline$V$ fifth & 7.1 & 1.3 & -1.1 & 1.5 & 6.4 & 0.1 & 13.9 & 32.1 \\
\hline
\end{tabular}

1 The I Fifth comprises households whose wealth lies below the first quintile; the $V$ Fifth comprises households whose wealth lies above the fourth quintile. The other Fifths are defined accordingly. 
Table B.2 (cont)

\section{Real capital gains between 1989 and 2004}

\begin{tabular}{|c|c|c|c|c|c|c|c|c|}
\hline \multicolumn{9}{|c|}{ Percentages } \\
\hline \multicolumn{9}{|l|}{ Town size } \\
\hline $\begin{array}{l}\text { up to } 20,000 \\
\text { inhabitants }\end{array}$ & 4.4 & 3.9 & 0.9 & 2.6 & 6.1 & 0.2 & 12.9 & 34.8 \\
\hline $20,000-40,000$ & 6.1 & 2.4 & 0.0 & 1.7 & 6.4 & 0.6 & 14.8 & 35.9 \\
\hline $40,000-500,000$ & 5.0 & 0.8 & -0.1 & -0.5 & 6.5 & 2.3 & 14.5 & 31.2 \\
\hline more than 500,000 & 14.5 & -3.8 & -8.9 & -5.8 & 4.8 & 1.9 & 19.8 & 21.0 \\
\hline \multicolumn{9}{|l|}{ Geographical area } \\
\hline North & 6.1 & 3.3 & 0.3 & 1.6 & 6.8 & 0.4 & 12.4 & 34.6 \\
\hline Centre & 8.5 & -2.6 & -3.1 & -1.4 & 3.2 & 4.7 & 23.8 & 34.9 \\
\hline South and Islands & 6.2 & 1.3 & -2.0 & -1.4 & 6.8 & -0.1 & 11.8 & 24.0 \\
\hline Total & 6.6 & 1.6 & -0.9 & 0.3 & 6.0 & 1.1 & 14.7 & 32.3 \\
\hline
\end{tabular}

Authors' calculations on data from the Bank of Italy's SHIW Historical Database. 
Table B.3

Real capital gains between 1989 and 2004, by source and wealth class

Percentage of net wealth valued at 2004 prices

\begin{tabular}{|c|c|c|c|c|c|c|c|c|}
\hline & $\begin{array}{c}1989- \\
1991\end{array}$ & $\begin{array}{c}1991- \\
1993\end{array}$ & $\begin{array}{l}1993- \\
1995\end{array}$ & $\begin{array}{c}1995- \\
1998\end{array}$ & $\begin{array}{c}1998- \\
2000\end{array}$ & $\begin{array}{l}2000- \\
2002\end{array}$ & $\begin{array}{l}2002- \\
2004\end{array}$ & $\begin{array}{c}\text { 1989- } \\
2004 \\
\text { Chain } \\
\text { indexes }\end{array}$ \\
\hline Wealth class ${ }^{1}$ & \multicolumn{8}{|c|}{ Dwellings } \\
\hline I fifth & 0.90 & 1.51 & 0.51 & 0.01 & 1.19 & 0.53 & 4.15 & 9.08 \\
\hline II fifth & 6.48 & 2.16 & 0.81 & -0.29 & 4.56 & 3.27 & 13.55 & 34.06 \\
\hline III fifth & 8.93 & 4.17 & 1.39 & -1.03 & 5.72 & 5.36 & 16.37 & 47.60 \\
\hline IV fifth & 8.38 & 4.11 & 0.32 & -2.31 & 4.97 & 5.42 & 17.09 & 43.28 \\
\hline V fifth & 9.53 & 2.89 & 0.29 & -1.60 & 3.87 & 4.72 & 15.06 & 39.20 \\
\hline Total & 8.87 & 3.26 & 0.46 & -1.58 & 4.28 & 4.79 & 15.38 & 40.14 \\
\hline Wealth class ${ }^{1}$ & \multicolumn{8}{|c|}{ Land } \\
\hline I fifth & -0.03 & -0.12 & -0.03 & -0.01 & 0.04 & 0.00 & 0.00 & -0.13 \\
\hline II fifth & -0.05 & -0.21 & -0.07 & -0.01 & 0.05 & 0.01 & 0.01 & -0.26 \\
\hline III fifth & -0.07 & -0.18 & -0.07 & 0.00 & 0.04 & 0.01 & 0.01 & -0.27 \\
\hline IV fifth & -0.08 & -0.18 & -0.07 & 0.00 & 0.05 & 0.01 & 0.01 & -0.28 \\
\hline$V$ fifth & -0.08 & -0.21 & -0.10 & -0.01 & 0.08 & 0.02 & 0.02 & -0.27 \\
\hline Total & -0.08 & -0.20 & -0.09 & -0.01 & 0.07 & 0.01 & 0.02 & -0.27 \\
\hline Wealth class ${ }^{1}$ & \multicolumn{8}{|c|}{ Firms } \\
\hline I fifth & 0.03 & -0.01 & -0.06 & -0.02 & 0.00 & 0.00 & 0.00 & -0.06 \\
\hline II fifth & 0.10 & -0.03 & -0.09 & -0.04 & 0.00 & 0.00 & 0.00 & -0.05 \\
\hline III fifth & 0.10 & -0.03 & -0.13 & -0.06 & 0.00 & 0.00 & 0.01 & -0.12 \\
\hline IV fifth & 0.14 & -0.05 & -0.12 & -0.07 & 0.00 & 0.00 & 0.01 & -0.09 \\
\hline$V$ fifth & 0.18 & -0.10 & -0.34 & -0.13 & -0.01 & 0.01 & 0.02 & -0.37 \\
\hline Total & 0.15 & -0.07 & -0.25 & -0.10 & -0.01 & 0.01 & 0.01 & -0.26 \\
\hline Wealth class ${ }^{1}$ & \multicolumn{8}{|c|}{ BTPs and Bonds } \\
\hline I fifth & -0.01 & 0.00 & 0.00 & 0.03 & -0.01 & 0.00 & 0.00 & 0.02 \\
\hline II fifth & 0.00 & -0.02 & -0.02 & 0.14 & -0.01 & 0.00 & 0.00 & 0.08 \\
\hline III fifth & -0.02 & -0.02 & -0.02 & 0.06 & -0.02 & 0.00 & 0.00 & -0.02 \\
\hline IV fifth & -0.03 & -0.02 & -0.03 & 0.12 & -0.04 & 0.00 & 0.00 & 0.00 \\
\hline V fifth & -0.13 & -0.04 & -0.12 & 0.39 & -0.14 & 0.01 & 0.01 & -0.02 \\
\hline Total & -0.08 & -0.03 & -0.08 & 0.27 & -0.10 & 0.01 & 0.00 & -0.01 \\
\hline
\end{tabular}

For footnotes, see the end of the table. 
Table B.3 (cont)

\section{Real capital gains between 1989 and 2004, by source and wealth class}

Percentage of net wealth valued at 2004 prices

\begin{tabular}{|c|c|c|c|c|c|c|c|c|}
\hline Wealth class ${ }^{1}$ & \multicolumn{8}{|c|}{ Stocks } \\
\hline I fifth & -0.03 & -0.05 & 0.02 & 0.47 & 0.22 & -0.54 & -0.02 & 0.06 \\
\hline II fifth & -0.05 & -0.13 & 0.07 & 1.37 & 0.71 & -1.04 & -0.02 & 0.90 \\
\hline III fifth & -0.05 & -0.08 & 0.07 & 1.36 & 0.77 & -0.83 & -0.02 & 1.21 \\
\hline IV fifth & -0.13 & -0.13 & 0.07 & 1.42 & 1.33 & -1.44 & -0.03 & 1.07 \\
\hline$V$ fifth & -0.58 & -0.25 & 0.14 & 3.92 & 3.42 & -3.60 & -0.06 & 2.85 \\
\hline Total & -0.38 & -0.19 & 0.11 & 2.88 & 2.55 & -2.72 & -0.04 & 2.13 \\
\hline Wealth class ${ }^{1}$ & \multicolumn{8}{|c|}{ Fixed-rate mortgages } \\
\hline I fifth & 0.23 & 0.17 & 0.34 & -0.26 & -0.03 & 0.05 & 0.01 & 0.51 \\
\hline II fifth & 0.07 & 0.12 & 0.10 & -0.21 & -0.01 & 0.03 & 0.03 & 0.14 \\
\hline III fifth & 0.07 & 0.09 & 0.08 & -0.16 & 0.00 & 0.01 & 0.01 & 0.10 \\
\hline IV fifth & 0.05 & 0.05 & 0.05 & -0.09 & -0.01 & 0.02 & 0.01 & 0.09 \\
\hline$\vee$ fifth & 0.02 & 0.03 & 0.02 & -0.08 & 0.00 & 0.01 & 0.00 & 0.00 \\
\hline Total & 0.04 & 0.05 & 0.04 & -0.10 & 0.00 & 0.01 & 0.01 & 0.04 \\
\hline Wealth class ${ }^{1}$ & \multicolumn{8}{|c|}{ Deposits and other residual components } \\
\hline I fifth & -3.97 & -2.81 & -1.97 & -2.42 & -1.80 & -1.73 & -14.48 & -26.33 \\
\hline II fifth & -2.49 & -2.11 & -2.26 & -1.50 & -1.09 & -1.21 & -9.74 & -18.95 \\
\hline III fifth & -1.77 & -1.33 & -1.31 & -1.02 & -0.69 & -0.75 & -6.33 & -12.59 \\
\hline IV fifth & -1.77 & -1.34 & -1.09 & -0.99 & -0.59 & -0.72 & -5.93 & -11.88 \\
\hline$V$ fifth & -1.84 & -1.08 & -1.01 & -0.98 & -0.78 & -1.06 & -6.56 & -12.69 \\
\hline Total & -1.90 & -1.27 & -1.14 & -1.04 & -0.76 & -0.98 & -6.70 & -13.13 \\
\hline Wealth class ${ }^{1}$ & \multicolumn{8}{|c|}{ Total capital gains } \\
\hline I fifth & -2.87 & -1.32 & -1.19 & -2.20 & -0.39 & -1.69 & 2.55 & -6.97 \\
\hline II fifth & 4.07 & -0.23 & -1.46 & -0.53 & 4.19 & 1.07 & 12.48 & 20.56 \\
\hline III fifth & 7.18 & 2.62 & 0.01 & -0.87 & 5.82 & 3.80 & 15.75 & 38.64 \\
\hline IV fifth & 6.56 & 2.43 & -0.87 & -1.92 & 5.71 & 3.30 & 16.52 & 35.02 \\
\hline$V$ fifth & 7.10 & 1.25 & -1.10 & 1.51 & 6.44 & 0.11 & 13.87 & 32.10 \\
\hline Total & 6.63 & 1.55 & -0.94 & 0.33 & 6.03 & 1.13 & 14.38 & 32.30 \\
\hline
\end{tabular}

1 The I Fifth comprises households whose wealth lies below the first quintile; the $V$ Fifth comprises households whose wealth lies above the fourth quintile. The other Fifths are defined accordingly.

Authors' calculations on data from the Bank of Italy's SHIW Historical Database. 


\section{References}

Attanasio, O., Banks, J., and S. Tanner (1998): Asset Holding and Consumption Volatility, National Bureau of Economic Research, NBER Working Papers, No. 6567.

Bank of Italy (2002): Italian Household Budgets in 2000, (edited by) G. D'Alessio and I. Faiella, Supplements to the Statistical Bulletin, new series, No. 6, January.

Bank of Italy (2006): I bilanci delle famiglie italiane nell'anno 2004, in I. Faiella, R. Gambacorta, S. lezzi and A. Neri (edited by), Supplements to the Statistical Bulletin, new series, Bank of Italy, No. 7, January.

Biancotti, C., D'Alessio, G. and A. Neri (2004): Errori di misura nell'indagine sui bilanci delle famiglie italiane, Bank of Italy, Temi di Discussione No. 520 - October.

Brandolini, A., Cannari, L., D'Alessio, G. and I. Faiella (2004): Household Wealth Distribution in Italy, Bank of Italy, Temi di Discussione No. 530 - December.

Cannari, L. and G. D'Alessio (1990): Housing Assets in the Bank of Italy's Survey of Household Income and Wealth, in C. Dagum and M. Zenga (edited by), Income and Wealth Distribution, Inequality and Poverty, Berlin, Springer-Verlag, pp. 326-334.

Cannari, L. and G. D'Alessio (1993): Non-Reporting and Under-Reporting Behaviour in the Bank of Italy's Survey of Household Income and Wealth, in Proceedings of the ISI 49th Session, Firenze, ISI, pp. 395-412.

Cannari, L., D'Alessio, G. and M. Paiella (2006): La ricchezza delle famiglie italiane: un'analisi territoriale, in Cannari L. and F. Panetta (edited by) "Il sistema finanziario e il mezzogiorno", Cacucci.

Cannari, L., D'Alessio, G. and A. Venturini (2003): La ricchezza delle famiglie nelle regioni italiane, in "Rivista economica del Mezzogiorno", Vol. a. XVII, No.1-2, pp. 47-85.

Cannari, L., D'Alessio, G., Raimondi, G. and A. I. Rinaldi (1990): Le attività finanziarie delle famiglie italiane, Bank of Italy, Temi di discussione, No. 136, July.

Casolaro, L., Gambacorta L. and G. Gobbi (2004): I prestiti bancari per l'acquisto di abitazioni in Italia e nell'area dell'euro, in "Quaderni di Economia Immobiliare", June, pp. 24-39.

D'Alessio, G. and I. Faiella (2002): Non-response behaviour in the Bank of Italy's Survey of Household Income and Wealth, Bank of Italy, Temi di discussione, No. 462, December.

ECB (2003): Structural Factors in EU Housing Market, March.

Edrey, Y. M. (2004): What are Capital Gain and Capital Loss Anyway, Virginia Tax Review, Vol. 24, p. 141-186.

Greenwood, D. T. and E. N. Wolff (1992): Changes in Wealth in the United States, 19621983: Savings, Capital Gains, Inheritance, and Lifetime Transfers, in "Journal of Population Economics", Vol. 5, No. 4, pp. 261-88.

Guiso, L. and M. Paiella (2005): The Role of Risk Aversion in predicting individual behaviour, Bank of Italy, Temi di discussione, No. 546, February.

Haig, R. (1921): The Concept of Income: economic and legal aspects, in R. Haig (edited by), The Federal Income Tax, New York, Columbia University Press.

Henley, A. (1998): Changes in the Distribution of Housing Wealth in Great Britain, 1985-91, in "Economica", Vol. 65, No. 259, pp. 363-80.

Henley, A. (2001): Capital Gains and Labour Supply: British Evidence, The University of Wales, School of Management and Business, Research Paper 2001-7.

Harris, M. (2001): The Income of Nations: Measurement with (what?) Theory?, La Trobe University, School of Business Discussion Papers, Series A, 01.09. 
Hendershott, P. H. and J. Peek (1985): Real Household Capital Gains and Wealth Accumulation, in P.H. Hendershott (edited by) The level and Composition of Household Saving, Cambridge, Massachusetts, Ballinger Publishing Company.

Hicks, J. (1939): Value and Capital, (second edition), Oxford, Clarendon Press, 1946.

Mankiw, G. and S. Zeldes (1991): The Consumption of Stockholders and Non-Stockholders, in "Journal of Financial Economics", Vol. 29, pp. 97-112.

Muzzicato, S., Sabbatini, R. and F. Zollino (2002): I prezzi delle abitazioni in Italia: una rassegna di temi metodologici e la costruzione di un nuovo indice, Bank of Italy, mimeo.

Paiella, M. (1999): Partecipazione ai Mercati Finanziari e Volatilitá dei Consumi: Una Soluzione all'Equity Premium Puzzle?, Università di Pavia, Italy, mimeo.

Paiella, M. (2004): Does wealth affect consumption? Evidence for Italy, Bank of Italy, Temi di discussione, No. 510, July.

Peek, J. (1986): Household Wealth Composition: The Impact of Capital Gains, Federal Reserve Bank of Boston, New England Economic Review, Nov/Dec, pp. 26-39.

Povellato, A. (1997): L'indagine sul mercato fondiario, in A. Povellato (edited by), II mercato fondiario in Italia, Rome, Istituto Nazionale di Economia Agraria, pp. 33-45.

Reiter, M. (1999): Asset Prices and the Measurement of Wealth and Saving, Economics Working Papers 396, Department of Economics and Business, Universitat Pompeu Fabra.

Schivardi, F. and R. Torrini (2004): "Firm Size Distribution and Employment Protection legislation in Italy", Bank of Italy, Temi di discussione, No. 504, June.

Shorrocks, A. F. (1983): The Impact of Income Components on the Distribution of Family Incomes, in "Quarterly Journal of Economics", Vol. 98, No. 2, pp. 311-26.

Simons, H. (1938): Personal Income Taxation, Chicago, University of Chicago Press.

Wolff, E. N. (1999): Wealth Accumulation by Age Cohort in the U.S., 1962-1992: The Role of Savings, Capital Gains, and Intergenerational Transfers, The Geneva Papers on Risk and Insurance, Vol. 24, No. 1, January, pp. 27-49.

Zollino, F. (2001): Personal Saving and Social Security in Italy: Fresh Evidence from a Time Series Analysis, Bank of Italy, Temi di discussione, No. 417, August. 